\title{
Identiteit: 'n vlietende entiteit Die politieke invloed op die Israelitiese stamme gedurende die tyd van die Rigters
}

\author{
Magdel le Roux
}

\begin{abstract}
Present discussions about the history of Israel pay a great deal of attention to the question of Israel as an ethnic group with a prominent, distinguishable and unique identity. By means of empirical facts, this article aims to show that the Israelite tribes were subjected to many different and divergent influences during the settlement period which contributed towards their identity. Because of limited space this article will concentrate only on the political identity but it does not deny the other important historical dimensions pertaining to the discussion. The political situation is therefore an instrument to illustrate that ethnical identity is not shaped in a vacuum, but is dependent upon events taking place in their vicinity. They form part of an allencompassing process. The conclusion drawn from this discussion is that Israel should not be understood as an identifiable entity, because history does not allow existing identities to stagnate, but strives to affirm and to renew.
\end{abstract}

\section{INLEIDING}

Identiteit kan baie moeilik omskryf word. Daar bestaan verskeie gangbare teorieë oor hoe 'Israel' identiteit verkry het, maar 'Israel' het waarskynlik nie met ' $n$ afgebakende identiteit die land Kanaän 'binnegekom' of daar gevestig nie. Hierdie studie poog juis om 'n oorsig te gee van die komplekse konteks waarbinne Israel se identiteit begin vorm aanneem het.

Die kwessie van Israel as etniese groep met 'n sterk onderskeibare en unieke identiteit geniet baie aandag in die jongste gesprek rondom die geskiedenis van Israel. Daar word deesdae algemeen aanvaar dat die Deuteronomistiese geskiedenis van die pre-monargale en monargale tydperk waarin die wordingsgeskiedenis van Israel vanaf die vestiging (ongeveer $1200 \mathrm{vC})$ tot met die val van Jerusalem in $586 \mathrm{vC}$ beskryf word, juis funksioneel was ten opsigte van Israel se identiteitskrisis ná die ballingskap toe hulle etniese identiteit skipbreuk gely het en selfs deur totale assimilasie en uitwissing bedreig is. Die funksie van hierdie geskiedskrywing deur die 
Deuteronomis was moontlik juis om identiteit te verleen aan 'n gemeenskap wat gevaar geloop het om hul eiesoortigheid te verloor (vgl Mullen 1993:5; Whitelam 1989:19-42). Moderne teorieë oor etnisiteit dui daarop dat so 'n wêreld- en groepskepping dikwels meer volgens behoeftes van die groep geskied as in ooreenstemming met die empiriese historiese werklikheid (vgl Mullen 1993:15, nota 37). Hierdie artikel tree nie met sodanige teorieë in gesprek nie en ontken nie die geldigheid al dan nie daarvan nie, maar wil sover moontlik juis empiriese gegewens aanwend om aan te toon dat die Israelitiese stamme gedurende die vestigingstydperk, 'n baie belangrike fase in hul wordingsgeskiedenis, aan baie verskillende invloede blootgestel was. Hierdie invloede het meegewerk tot hul identiteit as Israel. Om die identiteit van die Israelitiese stamme in die tyd voor die monargie te wil aandui, is daarom byna onmoontlik. Die verhaal illustreer dat identiteit moeilik definieerbaar is omdat geskiedenis so 'n dinamiese, hoogs vloeibare proses is. Die verloop van gebeure is egter moeilik om te begryp en die kompleksiteit van 'n historiese situasie dwing mens daartoe om die geskiedskrywing te reduseer tot dit wat in bronne beskikbaar is. Identiteit is dikwels ' $n$ kunsmatige matriks wat ons op die brondokumente kom lê.

Vanweë 'n gebrek aan ruimte word hier slegs 'n oorsig van die politieke invloed op die Israelitiese stamme gedurende die premonargale tydperk aangedui. Dit gaan hier spesifiek oor politieke identiteit - die gevoel dat 'n groep bymekaar hoort, wat saamstaan en saam mag uitoefen. Politieke identiteit is slegs ' $n$ onderdeel van 'n baie groter geheel van 'n kulturele en ekonomiese organisasie. In hierdie artikel dien die politieke situasie egter slegs as middel om te illustreer dat etniese identiteit nie in 'n vakuum gevorm word nie, maar afhanklik is van gebeure in die omgewing: dit wil sê, deel is van ' $n$ oorkoepelende proses wat in 'n komplekse netwerk van faktore meewerk. Hierdie verhaal wil ook wys op die realiteit dat identiteit nie 'n statiese entiteit is wat in absolute terme vasgevang kan word nie, maar dat identiteit gedurig groei en verander.

Vervolgens word daar eers ' $n$ kort oorsig van die politieke voorgeskiedenis (1720-1200 vC) van die land Kanaän gegee met die oog daarop om die náeffekte gedurende 1150-1000vC (wat beskryf word as die tyd van die Rigters) aan te dui, waama daar kortliks by die verskillende benaderings tot die verstaan van die 'intog' van die Israelitiese stamme stilgestaan gaan word. Daarna word aangedui hoedat anargie in die Beloofde Land onder andere 'n impuls in die identiteitsvorming van die Israelitiese stamme was en hoe die politieke 'struktuur' van die Israelitiese stamme gedurende die Rigtertyd moontlik daar uitgesien het. 


\section{DIE POLITIEKE VOORGESKIEDENIS (1720-1200 vC) VAN DIE LAND KANAÄN}

Teen die tyd dat die Israelitiese stamme in die land Kanaän gevestig het, het die land reeds 'n lang en betekenisvolle geskiedenis gehad met die invloed van vorige kulture en politieke invloede duidelik waarneembaar. Met die vestiging van die Israelitiese stamme was daar ook ander etniese groeperinge en magte in die land teenwoordig en was die invloed van verskeie buitelandse magte wat vroeër heerskappy in Kanaän gevoer het, nog aan die orde van die dag.

Die vroeë geskiedenis van die Israeliete is verweef met die ontplooiing van magte soos die Hyksos, Egiptenare, Hetiete, Libiërs, 'apiru en Assiriërs. Nadat die Hyksos uit Egipte en Palestina verdryf is, het Egipte 'n belangrike rol in die geskiedenis van Kanaän gespeel. Daarna het die Hetiete die noordelike dele van Palestina beheer tot ongeveer $1200 \mathrm{vC}$, en het die invloed en náeffekte van hierdie state nog geensins tot 'n einde gekom nie. Die koms van die Seevolke was ' $n$ bydraende faktor vir die agteruitgang van die Egiptiese houvas in Kanaän. 'n Groot deel van hierdie Seevolke, veral die Filistyne, het hulself in die suidelike gebiede van Kanaän gaan vestig en gedurende die Rigtertyd tot een van die mees gedugte vyande van die Israelitiese stamme ontwikkel. Hulle het in hierdie tyd sodanig mag uitgeoefen (Rgt 10:7; 13:5 ev; l Sm 4) dat die land Kanaän die verandering van sy naam na Palestina aan hierdie groepe te danke het. Die politieke en kulturele opset in Palestina is ingrypend deur die verswakking van Egiptiese mag beïnvloed. Die Arameërs het dié situasie uitgebuit om van die noordooste af Palestina binne te dring om later ' $n$ betekenisvolle politieke mag in hierdie gebied te word. Die Edomiete, Moabiete en Ammoniete het ook van die geleentheid gebruik gemaak om die oostelike Transjordanië te beset en sou later 'n belangrike rol as die bure van die Israelitiese stamme speel. Dit was waarskynlik ook gedurende hierdie periode dat die grootste deel van die Israelitiese vestiging in Kanaän plaasgevind het.

\section{DIE INVLOED VAN DIE HYKSOS}

Die Hyksos was vanaf 1720 tot ongeveer $1570 \mathrm{vC}$ in beheer van beide Egipte en die Kanaänitiese stadstate. Hulle hoofstad in Egipte was Tanis, of Awaris, in die noordoostelike deel van die Nyldelta. Van die regering van die Hyksos in Sirië-Palestina self weet ons nie veel nie, maar die uitwerking daarvan in die tyd van die Rigters dwing ons om meer aandag aan hierdie tydperk te gee.

Opgrawings het aangetoon dat daar veel groter en meer wydverspreide voorspoed onder die bewind van die Hyksos in Kanaän was as wat die 
Egiptiese verslae wou aantoon. Dit was aan die Hyksos te danke dat (i) die feodale stadstaatstelsel in die land Kanaän ingestel is waarop die Egiptenare later net kon voortbou; (ii) dat daar gebruik gemaak is van dwangarbeid; (iii) dat die Kanaäniete die strydwa in hul oorlogvoering gebruik het en (iv) Sirië-Palestina in die groot gebeure van die antieke Ooste betrek is. Hierdie invloede was nog in die Rigtertyd aan die orde van die dag. Die effek van die feodale stelsel, wat op die kontras tussen die heersersklas aan die een kant en die werkersklas (wat gebuk moes gaan onder swaar belastings en dwangarbeid) aan die ander kant klem gelê het, kon moontlik daartoe aanleiding gegee het dat sommige van die onderdrukte Kanaäniete hulle baie meer kon tuisvoel onder die meer egalitêre strukture van die Israelitiese stamme. Die Israeliete se stryd teen die Kanaäniete is uiteraard deur die gebruik van strydwaens bemoeilik en die land se blootstelling aan die groot gebeure in die antieke Ooste het dalk onnodig aandag op die belangrikheid van hierdie landjie gevestig.

Agmoses, stigter van die Agtiende Dinastie en Nuwe Koninkryk kon in $1570 \mathrm{vC}$ daarin slaag om die Hyksos uit Egipte te verdryf (Grant 1984:15), maar eers nadat die Hyksos se mag deur Toetmoses III (1480-1448; Schwantes 1965:83) by Megiddo (1479) en by Kades aan die Orontesrivier (1471) verbreek is, het die Egiptiese mag in Kanaän gedy.

\section{DIE EGIPTIESE HEERSKAPPY IN KANAÄN}

Die politieke infrastruktuur wat deur die Hyksos-regering nagelaat is in Kanaän het die Egiptiese farao's in staat gestel om daarop voort te bou én voordeel te trek uit die verdeelde situasie waarin die land gelaat is. Die land was in 'n aantal distrikte verdeel, elk gesentreer rondom 'n stadstaat en deur sy eie erfprins beheer.

'n Belangrike nalatenskap uit hierdie tyd, die Amarnabriewe (ongeveer 1400-1350vC; ontdek in 1887, Miller $\&$ Hayes 1986:65), getuig daarvan dat die plaaslike konings en Egiptiese offisiere in Kanaän tevergeefs by Egipte om hulp aangeklop het teen die aanvalle en strooptogte van sekere groepe in die land. Een so 'n groep is die 'apiru wat opvallende ooreenkomste met die Bybelse term ibri, Hebreër vertoon. In hierdie korrespondensie is herhaaldelik na hierdie groepe verwys wat ontwrigting en onrus veroorsaak deurdat hulle die plaaslike en Egiptiese gesag probeer aftakel het. Aharoni \& Avi-Yonah (1979:39) wys daarop dat dié briewe, ironies genoeg, ook vermeld hoe die stadstate in hul botsings met mekaar by dieselfde semi-nomadiese stamme gaan hulp soek het. Hierdie briewe het egter onbeantwoord gebly.

'n Rede waarom die 'apiru en ander groepe die feodale stelsel uitgedaag het was moontlik juis omdat die stelsel oorbodig begin word het. Dit wil voorkom 
asof die stadstaatbeginsel ook selfvernietigende, onderlinge oorlogvoering gegenereer het wat dit uiteindelik vir die Israeliete makliker sou maak om 'n vastrapplek in Kanaän te kry. Dit was waarskynlik ook met die 'apiru dat die Israelitiese stamme sou identifiseer in die land en hierdie groepe kon seker ook makliker by die Israelitiese stamme aanklank vind.

'n Effek van die feodale stelsel was moontlik ook dat die Kanaäniete reeds so gewoond geraak het aan 'n oorheerser van buite (wat die besluite kon neem) dat dit nie vir hulle vreemd was toe ander groepe soos die Filistyne en die Israeliete grootliks die leisels in Kanaän begin oorneem het nie.

Wanadministrasie was moontlik een van die redes waarom Egipte geleidelik sy houvas op Palestina sou verloor. Ander redes vir die agteruitgang van die Egiptiese invloed in Palestina kan egter ook gesoek word in die konfrontasie met die Hetiete, die Libiërs en die Seevolke, wie se teenwoordigheid direkte implikasies vir Palestina en sy mense ingehou het.

\section{Die Hetiete verswak Egipte se mag in Kanaän}

Palestina se posisie is sterk bepaal deur die stryd tussen die Hetiete en Egiptenare. Vroeg in die dertiende eeu vC (in die vyfde jaar van Ramses II, 1285: Noth 1983:30) het 'n belangrike veldslag tussen die leërs van die Egiptenaars en die Hetiete plaasgevind. Die veldslag het onbeslis geëindig maar Egipte het die slegste daarvan afgekom aangesien noordelike Sirië en aangrensende gebiede in die hande van die Hetiete geval het (Jagersma 1982:59). Dit het beteken dat die ryk van die Hetiete byna vanaf die Swartsee in die noorde tot onderkant Damaskus in die suide gestrek het (Redditt 1988:41). Mettertyd het sommige van die Hetiete eenvoudig met nieSemitiese elemente in Sirië en Palestina geassimileer. (Sommige meen selfs dat die Hetiete se voorouers verantwoordelik kan wees vir die prominente neuse wat by die Hetiete en latere inwoners van Palestina aangetref word, Eybers 1975:86.)

Uit die Amarnatablette kom dit na vore dat daar ook korrespondensie tussen die Egiptiese koningshuis en die Hetitiese konings was. Fragmente hiervan in Hetities is te Boghazköy (in die huidige Turkye) gevind (Redditt 1988:41).

Op die vooraand van die Rigtertyd (omtrent $1200 \mathrm{vC}$ ) is die Hetiete deur die Assiriërs oorrompel (Kapelrud 1966:32) en was hulle goed bewaakte geheim rondom die ontginning van yster reeds by die meeste nasies bekend. Assirië se oorwinning oor die Hetiete het egter nie die einde van Egipte se probleme beteken nie. Gedurende die regering van Mernefta (1234-1225vC; Schwantes 1965:97) en Ramses III (1197-1165vC) het die Libiërs Egipte verskeie kere aangeval. Egipte kon wel daarin slaag om die aanvalle af te weer, maar Egipte 
se heerskappy het groot skade gely (Jagersma 1982:59). Hierdie verdere verswakking van Egiptiese mag het veroorsaak dat Egipte sy houvas op Palestina begin verloor het sodat die vestiging van die Israelitiese stamme en ander landsoekers in Palestina vergemaklik is.

\section{Die Seevolke se invloed in Kanaän}

Die Seevolke, waarskynlik uit die omgewing van die Egeïese See, Ciprus en die kus van Klein-Asië afkomstig (Aharoni 1978:20), het moontlik eers by Kreta (Kaftor) aangedoen (Amos 9:7) voordat hulle per land (die vrouens en kinders per ossewa) en per see (met oorlogskepe) die kusgebiede van KleinAsië, Sirië en Egipte (1184-1153vC) binnegedring het. Hierdie gebeure is deur Ramses III (1175-1114vC) (Wright 1966:70) op die mure van die tempel in Medinet Habu (omtrent $1190 \mathrm{vC}$ ) in Bo-Egipte laat opteken. Die vestiging van een van die Seevolke, die Filistyne, in die kusvlakte van Kanaän, het die politieke geskiedenis van Israel bepalend beïnvloed. Dié volk se naam het, soos reeds genoem, die naam van die land geword na aanleiding van die Egiptiese woord prst (Noth 1983:35), of Filistyn.

Die Egiptenare het waarskynlik die vestiging van die Filistyne in die kusvlakte as ' $n$ geleentheid gesien om hulle as vasal, handelaars of opsieners van Egiptiese ryksbelange in Kanaän te laat optree (vgl Cross 1973:124). Dit was moontlik 'n rede hoekom die Filistyne so 'n groot mate van beheer in Kanaän kon oorneem ná die verval van die Egiptiese mag. Hamlin (1990:129)

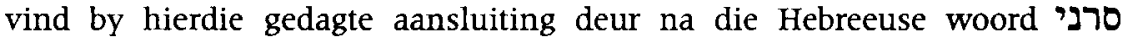
(Rgt 3:3) te verwys, wat vertaal word met 'vorste' (en ook as sulks die enigste oorblywende leenwoord van die andersins onbekende Filistynse taal is). Hy meen die woord is sinoniem met 'n Filistynse militêre aristokrasie wat die Kanaänitiese heersersklas vervang het.

Die 'mag' wat in die hande van die Filistyne geplaas is het moontlik bygedra tot hul vrymoedigheid om verdere uitbreidings in terme van Kanaänitiese stadstate te waag (vgl Wright 1966:76; Kapelrud 1966:32; Dothan 1987:39), maar die Filistynse imperialistiese neigings sou hulle, volgens die tradisie, ook in direkte konfrontasie met die Israelitiese Rigters Samgar, Debora en Barak, Jefta en Simson bring. Kapelrud is oortuig dat dit juis die tegniek vir die ontginning van yster (van Hetitiese oorsprong) was wat die Filistyne in die Rigtertyd die wapenvoorsprong bo die Israeliete gegee het, totdat laasgenoemde die ontginning daarvan self bemeester het. Oor dié sogenaamde voorsprong van die Filistyne bestaan daar egter heelwat twyfel (vgl bv Aharoni 1971). Hierdie eksterne bedreiging was volgens die Deuteronomistiese geskiedenis ' $\mathrm{n}$ belangrike faktor in die identiteitsvorming 
van die Israelitiese stamme omdat hulle gedwing is om saam te staan, wat uiteindelik ook aanleiding gegee het tot staatvorming.

Voordat die binnelandse politieke situasie onder die loep kom, word daar eers kortliks verwys na die uiteenlopende standpunte rondom die wyse waarop die Israelitiese stamme die land binnegekom het, wat noodwendig direkte implikasies vir die identiteit van die Israelitiese stamme gehad het. Dit was blykbaar net die instelling van die koningskap wat die finale oormag van die Filistyne kon stuit ( 1 en $2 \mathrm{Sm}$ ).

\section{DIE 'INTOG' EN DIE POLITIEK VAN DIE DAG}

Daar bestaan vandag onder Bybelse historici wyd uiteenlopende standpunte rakende die wyse waarop en die tyd wanneer die Israelitiese stamme die land Kanaän binnegekom het. Die een benadering sluit nie noodwendig die ander totaal uit nie en die meer omvangryke historiese rekonstruksie kombineer dikwels elemente van meer as een benadering.

Dié uiteenlopende standpunte het juis ontstaan as gevolg van die feit dat die weergawe van die intog in die boek Josua so drasties van dié in Rigters en van die argeologiese resultate verskil. Veral na gelang van die argeologiese bevindinge het die modelle van ' $n$ gewelddadige-inname-model tot by dié van 'n vreedsame, interne oorgang of verandering, ontwikkel.

Die klassieke veroweringsmodel veronderstel 'n gewelddadige inname van die land Kanaän deur die Israelitiese stamme. Hierdie benadering aanvaar volgens Hayes \& Miller (1977:264) die intog soos deur die samestellers van die Deuteronomistiese geskiedenis (spesifiek in die boek Josua) beskryf as histories korrek. Volgens hierdie tradisie het die twaalf Israelitiese stamme as 'n eenheid uit Egipte gevlug, in die woestyn vertoef en met geweld 'n groot deel van Transjordanië en byna die hele gebied wes van die Jordaan aan die einde van die Laat Bronstyd verower (Hayes \& Miller 1977:264). Dié veroweringsmodel is veral deur die Amerikaanse argeoloog, Albright (1957) voorgestaan.

Argeologiese getuienis het egter baie sterk téén hierdie gedagte van 'n gewelddadige inname gespreek en geleerdes is genoodsaak om aanpassings in hul standpunte te maak. Miller (1987:58) het onder andere daarop gewys dat daar met die klassieke veroweringsmodel nie met die beskrywing van die intog in Rigters 1 en 2 rekening gehou word nie. Stede wat reeds as Josua en die hele Israel se 'verowerde gebiede' genoem word (bv Hebron en Debir, Jos 10:36-39) is volgens Rigters 1:9-15 deur individuele aksie ingeneem en sommige is nooit ingeneem nie.

Op grond van die Vormkritiek het geleerdes soos Alt, Noth en Weippert die standpunt ontwikkel dat die Israeliete as nuwelinge en landelike semi- 
nomades, die Palestynse bodem eerder op 'n vreedsame wyse binnegedring het op soek na nuwe weivelde. Met dieselfde analitiese metode het Alt (1925) uit die Amarnabriewe en ander historiese dokumente die afleiding gemaak dat die Israeliete hulself veral in die yl bevolkte sentrale heuwellande begin tuismaak het. Dever (1993:53) wys daarop dat dié teorie juis ' $n$ manier is waarop die teoretici die argeologiese getuienis en teenstrydige verslae in die boeke Josua en Rigters probeer akkommodeer, en kritiseer veral hul hantering van die argeologie en verwysings na die nomadiese oorspronge vir die Israelitiese stamme (vgl ook Mendenhall 1962:66; Finkelstein 1988:302-306).

Mendenhall (1962:73) het trouens die gedagte op die tafel geplaas dat daar nie 'n grootskaalse oomame of verskuiwing van mense plaasgevind het nie, maar dat die proses moontlik meer akkuraat as ' $\mathrm{n}$ peasant revolt beskryf kan word. In plaas van die nomadiese oorspronge stel hy voor dat die stamme (of Hebreërs van die Bybel) met die 'apiru waarna die Amarnabriewe verwys, verbind moet word. Hierdie situasie was vanuit 'n sekulêr-geskiedkundige oogpunt 'n sosio-politiese proses, wat op 'n 'boereopstand' teen die verstrengelde netwerk van die Kanaänitiese stadstate neergekom het (1962:73). Veral Gottwald (1979) het by hierdie teorie aanklank gevind, maar pas dit net meer uitgebreid en sistematies toe. Hy verklaar die verskyning van Israel in die twaalfde eeu $\mathrm{vC}$ as ' $\mathrm{n}$ anti-staat-stammeopstand van onderdrukte boere op die Kanaänitiese platteland. Hy noem dit 'n egalitêre sosioekonomiese beweging.

Fritz (1987:84) meen dat dié rewolusieteorie 'n moeisame verduideliking van die toestande wat tot die rewolusie en reorganisasie gelei het, vereis en kritiseer die hipotese vir sy onvermoë om voldoende redes vir hierdie ontwikkeling te gee. Die teorie wat Fritz (1987:98) en ander erkende Ou Testamentici ondersteun, is die gedagte van 'n interne nomadisme of simbiose. In sekere opsigte stem dit met die infiltrasiemodel van Alt en ander ooreen, maar veral ten opsigte van die nomadiese leefwyse van die Israelitiese stamme is ' $n$ paar veranderings aangebring. Hy noem die Israelitiese stamme 'culture-land nomads' wat agter weiding aan getrek het maar wat vir langer periodes as byvoorbeeld Bedoeïene in die woestyn, hulle naby woongebiede gevestig het. Hierdie periodes was seisoenaal bepaal en het daartoe aanleiding gegee dat ' $n$ soort simbiose met die Kanaänitiese stadstate gehandhaaf is. Fritz meen dat daar selfs 'n soort politieke simbiose ontwikkel het en later ook 'n geleidelike oorname van kultuurgoedere. Vanweë hierdie simbiotiese bestaan was die Israelitiese stamme in staat om hierdie groter stede ná hul ineenstorting (ongeveer $1150 \mathrm{vC}$ ) te beset en 'n permanente bestaan hier te begin voer, aldus Fritz (1981:98). Hy is ook oortuig dat die 
materiële kultuur ' $n$ vermenging van ou en nuwe voorwerpe toon, sodat die Ystertydperk beslis ' $n$ voortgang van die Laat Bronskulture op die meeste terreine verteenwoordig. Die realiteit is egter dat hulle min van die stede in werklikheid kon beset sodat daar alle rede is om te glo dat dié simbiose op baie terreine nog in die tyd van die Rigters voortgegaan het, kontra Fritz (1981:98).

Finkelstein (1988:270-291, 315-323) lê veral klem op die verskil in kultuur tussen die Kanaäniete en die Israeliete. Hy benadruk dat die Israeliete as ' $\mathrm{n}$ aparte groep mense in die land as nomades geleef het; die kontinuïteit tussen die kulture het ontstaan weens die eeuelange simbiose tussen hierdie groepe veral op ekonomiese gebied.

Ook ander modelle wat hierna gevolg het, beklemtoon Israel se vredevolle en interne oorspronge - terme soos 'vredevolle oorgang' of 'verandering' is algemeen. Dit is betekenisvol om daarop te let hoedat die politiek van die dag ook 'n uitwerking gehad het op die formulering en totstandkoming van bogenoemde teorieë en modelle.

As 'n keuse gemaak moet word, aanvaar ek graag dié projeksies wat die oorspronge van Israel in die land self gaan soek, soos die Bybelse tradisies rondom hulle voorvaders reeds aandui. Hierdie tradisies sê pertinent dat die Israelitiese voorvaders voor die uittog reeds in die land Kanaän gevestig het. $\mathrm{Na}$ aanleiding van die inligting uit die Merneftastele, die inskripsie by Betsean en die Amarnabriewe, kan die Hebreërs van die Bybel (ook so in Egipte genoem) waarskynlik wel met die 'apiru (of Hebreërs) in die land tydens die vestiging verbind word. Die moontlikheid van 'n ekonomiese maar ook ' $n$ politieke simbiose is ' $n$ gedagte waarop voortgebou moet word. Die moontlikheid dat 'n sekere groep (moontlik die Josefstamme), wel later sekere gebiede gewelddadig ingeneem het, soos Deist \& Du Plessis (1985) dit ook voorstel, en dat dié tradisie later dié van die hele volk geword het, is nie te vergesog nie. Dié tradisie van 'n gewelddadige inname is uiteindelik te sterk in die herinneringe van die Bybelskrywer/s om sommer net totaal te ignoreer.

\section{ANARGIE IN DIE BELOOFDE LAND}

Ander belangrike inligting wat vanuit die Egiptiese annale behoue gebly het, is die verwysing na 'Israel' op die bekende Merneftastele (1220vC; ontdek in 1895 nC; ANET:376-378). Hierdie verwysing dui moontlik daarop dat die Israelitiese stamme reeds aan die einde van die dertiende eeu 'n deel van Palestina begin beset het en 'n groep was waarmee deeglik rekening gehou moes word. Uit die verslae van die Egiptenaar Wen-Amun (1076 vC; Noth 1983:35) kan ons aflei dat die Egiptiese mag en prestige in Sirië en Palestina 
in die periode van die Rigters besig was om af te neem (vgl Bright 1972:168). Hierdie verwikkeling, tesame met die buitelandse politiek binne die Kanaänitiese stadstate, die bedreiging van die Israeliete se bure op hul 'grense' en die ander etniese en onafhanklike groepe in Kanaän, het die land haas 'onregeerbaar' gelaat. Ons kan moontlik sê dat anargie in die land enersyds deur die etniese samestelling en politieke situasie binne die land aangehelp is, maar andersyds is dit ook deur hulle direkte bure versterk. Anargie in die Beloofde Land kon waarskynlik vir die Israeliete as impuls tot polities-militêre identiteitsvorming dien - dit het die stamme gedwing om saam te staan en in tye van nood mekaar te ondersteun.

Dit was egter eers ná die proses van vestiging dat die verdeelde en ongelyksoortige elemente in die land tot 'n verenigde politieke, etniese en godsdienstige eenheid kon begin konsolideer.

\section{DIE BURE VAN DIE ISRAELITIESE STAMME GEDURENDE DIE RIGTERTYD}

Ná die agteruitgang van die Egiptiese mag in Kanaän, is die vyande van die Israelitiese stamme tot die 'Kanaäniete' en die bure op die 'grense', beperk. Daar was nog nie sprake van werklike grense in vandag se terme nie, maar die oostelike Transjordanië was reeds deur die Edomiete, Moabiete en Ammoniete bewoon, almal volke wat ook op een of ander manier aan Israel verwant was, maar wat met die verswakking van Egipte hulle eie onafhanklike 'koninkryke' gestig het. Hoe hierdie koninkryke daaruit gesien het, is baie onseker. In die noorde het die Arameërs en Feniciërs 'n tuiste gevind en in die suide het die semi-nomadiese stamme van die Midianiete en die Amalekiete rondbeweeg.

Met die Edomiete, in die berge suidoos van die Jordaan, het die Israeliete waarskynlik nie veel kontak gedurende die Rigtertyd gehad nie. Waarskynlik as gevolg van die feit dat die koning van Edom volgens die tradisie (Num 20:14-21) geweier het dat die Israelitiese stamme deur sy gebied langs die Koningsweg na die land Kanaän kon trek, was daar nie 'n baie goeie verhouding tussen hierdie twee groepe nie en moes daar seker met Edom rekening gehou word (Rgt 11:17; Aharoni \& Avi-Yonah 1979:52).

Die Moabiete, in die gebied oos van die Dooie See, tussen die Arnon- en Seredriviere, se uitbreidingsdrang (Rgt 3:12-30; Noth 1983:156) het hulle in konflik met die Israelitiese stamme gebring. Tydens hierdie uitbreiding is die Benjaminiete aan die Moabiete skatpligtig gemaak en moes die Rigter Ehud hulle uit die situasie 'bevry'. Dié verhaal van Ehud is waarskynlik een van die oudste tradisies aangaande die Rigters (Richter 1964:113-141). 'n Andersoortige kontak met die Moabiete was klaarblyklik by die altaar Baal-Peor, tussen die noordelike punt van die Dooie See en Hesbon. Hier het Israeliete, 
hoofsaaklik uit die stam van Gad, en Moabiete by die grensaltaar ontmoet en saam aanbid (vgl Num 25; Noth 1983:155). Die proses van simbiose was duidelik nie net tot die ekonomiese en politieke terreine beperk nie. Ten spyte van die gemeenskaplike deelname aan die kultus by Baal-Peor was die verhouding met dié bure nie noodwendig vriendelik nie. In Rigters 11:17, 18 word ook weer die weiering van beide Edom en Moab om die Israeliete deur hul gebied te laat trek, in herinnering geroep. Van Zyl (1960:118) beskryf die verhouding tussen die Moabiete en Israelitiese stamme as soortgelyk aan 'n moderne 'koue oorlog'.

Die Ammoniete noordoos van Moab het volgens Thompson (1988:30) ook lank vóór Israel reeds 'n soort monargie gehad. Dit wil voorkom asof die Ammoniete aanvanklik nie veel kontak met die Israelitiese stamme gehad het nie (Rgt 11:15) omdat hulle te ver weg gewoon het, maar daar het later, toe die Efraimiete die antieke land Gilead gekoloniseer het en die Ammoniete noord-wes wou uitbrei, wel wrywing gekom (De Vaux 1978:518). Die verhaal van Jefta (Rgt 10:6-12:6) vertel van ' $n$ aanval op Gilead, oos van die Jordaan (Noth 1983:158). Volgens Rigters 3 was die Ammoniete bondgenote van koning Eglon van Moab, wat Benjamin onderwerp het, maar hulle het waarskynlik nie self deel gehad aan dié spesifieke aksie nie (De Vaux 1978:518).

As deel van die migrasie uit die rigting van die Arabiese woestyn, het die Feniciërs, ook van Semitiese oorsprong, hulle in die smal strook tussen die Middellandse See en die berge van Libanon gevestig (Harrison 1970:40). Teen 1200 vC was die Feniciërs reeds 'n hoogs beskaafde groep wat met die val van die Hetitiese en Egiptiese mag ook hulle politieke onafhanklikheid kon bevestig. 'n Aantal onafhanklike stadstate het in Fenicië ontstaan, waarvan die belangrikste seker Tirus en Sidon was (Harrison 1970:40). In die Bybel word ook die Feniciërs dikwels die Kanaäniete of Sidoniërs genoem, na aanleiding van die stad Sidon. Die Feniciërs het gedurende die Rigtertyd reeds 'n alfabet ontwikkel wat later as 'n model vir die geskrewe tale van die Mediterreense wêreld gedien het. Daarsonder sou die bronne vir hierdie studie soveel meer beperk gewees het. Die feit dat daar hoegenaamd buiteBybelse geskrewe bronne uit die tyd van die Rigters bestaan, is aan hierdie ontwikkeling te danke. Dit is myns insiens nie uitgesluit dat die lied van Debora direk na die gebeurtenis wat dit beskryf, opgeteken is nie.

Die Hebreeuse patriarge, van Semitiese oorsprong, het hulle waarskynlik ná hul vertrek uit Ur (omtrent $2000 \mathrm{vC}$ ) eers in bo-Mesopotamië by Haran, dit is Aram-naharaim gevestig (Gn 1 1:28-32). Kitchen (1988:67) meen dat 'n deel van die familie daarna waarskynlik as 'Arameërs' agtergebly het terwyl die ander (waarskynlik dan Abraham, volgens die Bybelse tradisie) na 
Kanaän getrek het. Die vroue van beide Isak en Jakob het uit die Aramese tak van die familie gekom (Gn 24:28 ev). Hy is oortuig dat dié verklaring ook die latere Israelitiese belydenis 'My vader was 'n swerwende Arameër' (Dt 26:5) verhelder. Hoewel die Israelitiese stamme hulleself as verwant aan die Arameërs beskou het, is Fensham en Pienaar (1982:84) van mening dat die Israeliete direk na hierdie belydenis, juis na hul verblyf in Egipte verwys omdat hulle hulself ook duidelik van die Arameërs in Mesopotamië wou onderskei. 'n Groep Arameërs het hulle vir 'n tyd lank suid van die Jabbok in die ooste van die land Gilead gevestig en het later volgens Harrison (1970:40) hulleself in ' $n$ aantal klein koninkryke rondom stede soos Damaskus, Kades en Palmyra georganiseer. Die Manassiete (Magir) se uitbreiding na die land noord van die Jabbok, het die Israelitiese stam in direkte kontak met die Arameërs gebring (Noth 1983:159). Volgens Rigters 3:7-1 1 was een van die Israeliete se onderdrukkers in die tyd van die Rigters juis die opportunis Kusanrisataim, die koning van Aram, of Aram-naharaim (vgl Bright 1972:172; Kitchen 1988:68). Die historiese interpretasie van dié onderdrukking is baie onseker en sommige geleerdes beveel aan dat 'Edom' in plaas van 'Aram' gelees moet word. Aangesien 'n distrik kusa-rama (Kûshan-rom) wel in ' $n$ lys van gebiede in noordelike Sirië (van Ramses III) voorkom, kon die inval tog wel moontlik uit hierdie rigting gekom het (Bright 1972:172).

Gedurende die Rigtertyd het die assosiasie tussen die Arameërs en die inwoners van Sirië al hoe sterker geword - teen die negende eeu was die terme Siriërs en Arameërs wisselvorme. Die Arameërs het klaarblyklik al hoe meer in die noorde van Palestina gesag begin verkry. Dit blyk uit Rigters 18:9, 28 (in LXX, De Vaux 1978) dat die Daniete alleenlik die stad Laïs in besit kon neem omdat dit geen verbintenis met die Arameërs gehad het nie. Hieruit lyk dit of Sirië en Mesopotamië dieselfde tipe probleme met die Arameërs, as die Kanaäniete met die Israeliete gehad het (Fensham \& Pienaar 1982:84). Die ooreenkomste is opvallend: nomadiese Arameërs op soek na kos en weiding het Sirië eenvoudig binnegeval en chaos veroorsaak. Die deel van die land wat Sirië self beheer het, het al hoe kleiner geword en al hoe meer nomadiese stamme het in Sirië gevestig geraak totdat hulle eenvoudig as deel van die bevolking aanvaar is en grootliks die gesag oorgeneem het. Dan is die moontlikheid boonop daar dat die Arameërs en die Israelitiese stamme aan mekaar verwant was.

Teen die tyd dat die Israelitiese stamme in Palestina begin vestig het, het ' $\mathrm{n}$ ander groep nomadiese stamme, die Midianiete, op hulle beurt weer die Israeliete se vrede kom versteur. Die hoofweivelde van die nomadiese Midianiete was aan die oostelike kant van die golf van Akaba (Noth 1983:83) geleë. Die suid-oostelike punt van Palestina was gedurende die Rigtertyd 
blootgestel aan aanvallers uit die woestyn. Van hierdie situasie het die Midianiete jaarliks gebruik gemaak. Hierdie groepe uit die woestyn het nie soseer die Israeliete se grond bedreig nie, maar wel hulle gesaaides op die lande en ander produkte in die skure. Die jaarlikse verskyning van die Midianiete het geweldige paniek gesaai. Die gepaardgaande terreur kan nog in die storie van Gideon, 'n baie ou tradisie, aangevoel word. Daar word verwys na 'kamele sonder tal' (Rgt 6:5; 7:12) en hoe die Israeliete probeer ontvlug het deur in elke moontlike skuiling in die berge, grotte en op bergtoppe weg te kruip (Rgt 6:2; Noth 1983:161).

Behalwe die Midianiete was die Amalekiete óók 'nomadiese' stamme wat suid van Palestina in die Negev rondbeweeg het. Volgens Rigters 12:15 het hulle op 'n manier ' $n$ houvas in Efraim begin kry (Thompson 1988:28). Uit die tyd van die Rigters is daar veral twee verhale bekend waarby die Amalekiete betrokke was. Volgens Rigters 3:13 het die Amalekiete koning Eglon van Moab se aanval op Israelitiese gebied gesteun, en later (Rgt 6:3-5, 33; 7:12; 10:12) het hulle ook ewe opportunisties hul gewig by die Midianiete ingegooi om die Israeliete se produkte en vee te buit.

Behalwe die bure rondom die Israelitiese stamme was die verskeidenheid etniese groepe binne die land ook 'n belangrike faktor wat bygedra het tot die anargie in die land. Te midde van hierdie verskeidenheid invloede en die ou uitgediende politieke strukture moes die Israelitiese stamme 'n tuiste vind en hul identiteit probeer behou of moontlik eers vind.

\section{DIE ETNIESE KOMPOSISIE VAN KANAÄN}

Die Kanaäniete of die Israelitiese stamme was kennelik nooit die alleenbesitters van die land Palestina nie. Behalwe die Kanaäniete noem die Bybel ook nog onder andere die Amoriete, die Horiete, die Hewiete, die Feresiete, die Jebusiete, die Girgasiete, die Hetiete en die 'apiru, wat in die land teenwoordig was. Die woord Kanaäniet word dikwels in die Bybel vir die nieIsraelitiese inwoners van die land gebruik. As gevolg van die konglomeraat van nasies kan die land Kanaän veel makliker as die woord Kanaäniet omskryf word. Die Kanaäniete het geen sentrale hoofstad gehad of geen noemenswaardige nasies oorheers nie. Vir inligting oor die Kanaäniete is ons dus afhanklik van ander volke se verslae. Tog was die Kanaäniete aan die begin van die Rigtertyd steeds dié belangrikste bevolkingsgroep wat in terme van politiek, kultuur en samelewing die grootste invloed op hul omgewing uitgeoefen het (Jagersma 1982:76). Die streng hiërargiese politieke stelsel van die Kanaänitiese stadstate sou uiteraard 'n belangrike invloed uitoefen veral wanneer belastings gehef en dwangarbeid aan die orde gekom het (Mayes 1985:43). 
Een van die etniese groepe, se naam, die Amoriete, was waarskynlik ook 'n etnografiese gebruik van die woord Kanaäniet. Noth (1966:77) meen dat die Akkadiese naam vir die 'Weste' as die 'land van Amurru' bekend gestaan het eweneens is alles wat van dié gebied afgekom het, 'Amorities' genoem.

Die Horiete of Goriete was moontlik (Mazabow 1973:28) verwant aan die Hurriane.

Die Hewiete (Mazabow 1973:28) het volgens die boek Josua, in Sigem (Jos 9; vgl Rgt 3:3) en vier ander stadstate wes van Jerusalem gewoon, en al vier die stadstate het in 'n vredevolle alliansie met die Israelitiese stamme getree. Mazar (1981:78-79) meen dat die verbond of alliansie van die Hewiete en Gideoniete met die Israeliete in die heiligdom of 'huis' van Elberith-Baal-berith (die Heer van die Verbond) gesluit is.

Die Feresiete word in die Ou Testament (bv Gn 13:7, 34:3; Rgt 1:4-11) saam met die Kanaäniete as een van die twee hoofgroepe in Kanaän genoem (Singer 1901:640). Hulle was waarskynlik 'n semi-nomadiese groep wat in oop dorpe of nie-ommuurde stede gewoon het en wie se naam suggereer dat hulle ook Semities van oorsprong was (Van Selms 1967:193).

Van die Jebusiete en Girgasiete weet ons baie min. Volgens Rigters 19:10-12 lyk dit of die Jebusiete die Kanaäniete was wat Jebus ingeneem het. Die gebied van die Girgasiete, wes van die Jordaan kon nog nie gelokaliseer word nie (Mazar 1981:79).

Noth (1966:77) is van mening dat die term 'Hetiet' moontlik ook 'n etnografiese gebruik kon gehad het. Die Mesopotamiërs het na Sirië en Palestina as 'die land van Hatti' in die Laat Bronstyd verwys, waarvan die term 'Hetiet' ook afgelei is (Gn 23:3 ev; 26:34;27:46;49:29,30). Soos in die geval van die Hewiete en Jebusiete was hier nie sprake van 'n monargie nie. maar wel ' $n$ aristokrasie. Die belangrikheid van dié groep is onder andere dat hulle direkte bure van die Israelitiese stamme in die heuwelland was (vgl Rgt 1:22-26). Hierdie groepe het geleidelik ondertrou en is opgeneem in die Israelitiese gemeenskap. Mazar (1981:78) is oortuig dat daar ook botsings tussen hierdie groepe en die Israelitiese stamme in die heuwellande moes plaasgevind het.

Bright (1972:107) waarsku dat die Hetiete wat as deel van die bevolking in Kanaän beskryf word, nie met dié van die Hetitiese Ryk verwar moet word nie want laasgenoemde se mag het nie so ver suid gestrek nie. Die Hetiete van die Bybel was, volgens Bright, moontlik 'n groep Hurriane, wat ook IndoAriaanse elemente bevat het. Ander meen, kontra Bright, dat 'n groep Hetiete hulleself wel in die noorde van Palestina, kort na die verval van die Egiptiese mag in Kanaän, kom vestig het.

'n Laaste belangrike element van die bevolking wat in ag geneem moet 
word is die 'apiru. In Sumeriese, Assiriese, Babiloniese en Hetitiese tekste word daar onder andere na hierdie groepe as Hapiru of Habiru verwys, wat moontlik op 'n verbintenis met die Hebreërs van die Bybel dui (Lemche 1988:86). Dit is duidelik dat die term 'apiru baie wyd in die Nabye Ooste voorgekom het en dat dit lyk asof hulle mense was wat om een of ander rede hul tuisgebiede moes verlaat en nie kon terugkeer nie (Lemche 1988:86). Die meeste geleerdes aanvaar dat hierdie ' $n$ sosiale groepering was en nie ' $n$ etniese eenheid nie. Jagersma (1982:12) wil ten minste sê dat sommige van die voorvaders van wat later as Israel bekend gestaan het, deel van die groep was wat in die buite-Bybelse tekste 'apiru genoem word. By dié gedagte wil ekself ook aansluit. Die 'apiru-probleem moet in berekening gebring word indien ons 'n duideliker prentjie van die alternatiewe gemeenskap wat gedurende die Rigtertyd in die heuwellande van Palestina ontstaan het, wil probeer vorm (Lemche 1988:89). Dat die Israelitiese stamme met hierdie groepe sou identifiseer is hoogs waarskynlik; ook in latere jare sou hulle met die gedagte van 'vreemdeling' wees in die land kon assosieer. Die Israelitiese stamme en die 'apiru was in 'n soortgelyke situasie en het ten minste baie in gemeen gehad.

Mazar (1971:9) wys ook nog op verdere groepe wat 'n belangrike plek ingeneem het en ook met die Hebreërs van die Bybel verbind word: seminomadiese stamme in die grensgebiede wat Shasu in Egiptiese bronne genoem word; verskeie afhanklike elemente soos dienaars en slawe; die hanikim, soldate wat in die state se lëermag gedien het en die asiru of krygsgevangenes.

Al bogenoemde elemente het uiteraard tot die kompleksiteit van die politieke situasie in die land bygedra sodat die Israeliete hulle in ' $n$ land met 'n 'etniese en sosiale heterogeniteit en 'n verdeelde bevolking,' bevind het (Noth 1966:76).

\section{'N POLITIEKE SIMBIOSE RONDOM DIE KANAÄNITIESE STADSTATE}

Oor die kompleksiteit van die politieke situasie in die land gedurende die Rigtertyd kan daar geen twyfel bestaan nie maar dit is waarskynlik nog meer problematies om die politieke struktuur waarvolgens die Israelitiese stamme gefunksioneer het, te bepaal. Dit het waarskynlik nie soseer gegaan oor wié het wáár gewoon nie, maar wie het beheer uitgeoefen en, watter invloed het daarmee gepaard gegaan. Die Kanaänitiese stadstate sou uit die aard van die saak aan die begin van die Rigtertyd nog 'n groot politieke voorsprong bo die Israelitiese stamme (in dié verband) hê wat maar op losse wyse in die land gevestig het. Mettertyd is al hoe meer stadstate óf deur die Filistyne óf deur die Israeliete oorgeneem of beset. Geleerdes soos De Geus (1976), Fritz (1981) en Finkelstein (1988) is dit eens dat daar gedurende die Laat Bronstyd 
(sommige meen selfs vroeër) 'n ekonomiese interafhanklikheid (simbiose) tussen die stadstate aan die een kant en die Israelitiese stamme en ander etniese en onafhanklike groepe aan die ander kant ontwikkel het. Uit die aard van die saak sou hierdie situasie geleidelik tot 'n politieke simbiose ontwikkel wat ook 'n uitruil van kultuurgoedere tot gevolg kon hê (vgl Finkelstein 1988:270-291). Ander geleerdes (bv Hamlin 1990 en Gottwald 1979) is oortuig dat hierdie interafhanklikheid nie eensklaps met die val van die Kanaänitiese stadstate verdwyn het nie, en hierby sluit ek graag aan, maar dat hierdie simbiose steeds tot in die Rigtertyd voortgeduur het.

$\mathrm{Na}$ aanleiding van Rigters 1 toon Hamlin (1990:14) ' $\mathrm{n}$ paar belangrike politieke scenarios aan waarin die Kanaänitiese stadstate hulle ten opsigte van die Israelitiese stamme in die Rigtertyd bevind het.

In die suide het sommige van die Israelitiese stamme so sterk na vore getree dat ou politieke strukture plek moes maak vir nuwes (Rgt 1:1-17).

In die sentrale dele van die land 'het die Kanaäniete verkies om in die land te bly' (Rgt 1:32-33; Hamlin 1990:14), maar hulle moes hier waarskynlik as 'n minderheidsgroep tussen die Israeliete woon.

In die noorde was die Israeliete moontlik weer in die minderheid teenoor die meer dominante kultuur van die Kanaäniete. Juis in die lig van die gebeure in die twaalfde eeu meen Hamlin (1990:44-46) dat Rigters 1:27-33 'n situasie van magsdeling in die land suggereer. Die situasie van magsdeling in die stamgebiede van Sebulon, Issaskar en Naftali, waar die inwoners van die Kanaänitiese stadstate ook nie deur die Israeliete verdryf is nie, noem Hamlin (1990:45) '... self-sufficient villages surrounding Canaanite cities ...'. Die stam Aser was egter weer omring deur Kanaänitiese stede waarvan die Israeliete nie die inwoners kon verdryf nie (Rgt 1:31).

Gottwald (1985:30) kom effektief baie naby aan die gedagte van magsdeling deur sy stelling dat 'n breë alliansie van stamme in die gebied van Efraim en Manasse veral die sosio-ekonomiese, religieuse en militêre funksies in hierdie gebiede sou oorneem. Hy vermoed dat die alliansie uit verskillende groepe, waaronder die afstammelinge van die groep Hebreërs wat uit Egipte gekom het én Kanaäniete wat verarm en uitgebuit gelaat is deur die onderdrukkende maatreëls van die stadstaatstelsel, kon bestaan het. Die feit dat daar in die stamgebied van Efraim net ' $n$ paar onbelangrike Kanaänitiese stadstate was en dat daar, soos Aharoni (1971:113) dit beskryf, feitlik 'n deurlopende, uniforme Israelitiese bevolking was, kon meegewerk het tot die dominante rol wat Efraim later in die stammeorganisasie gespeel het.

Die politieke simbiose het oënskynlik sonder noemenswaardige konflik plaasgevind: 'So het die kinders van Israel dan onder die Kanaäniete, Hetiete 
en Amoriete en Feresiete en Hewiete en Jebusiete gewoon, en húl dogters vir hulle as vroue geneem en hulle eie dogters aan húl seuns gegee en hul gode gedien' (Rgt 3:5, 6). In hierdie situasie sou die identiteit van die Israelitiese stamme vorm aanneem en voortdurend wissel en op politieke gebied sou daar mettertyd iets nuuts na vore kom, moontlik omdat die verskillende groepe in die land noodgedwonge by die veranderde omstandighede moes aanpas.

\section{DIE STAMMEORGANISASIES OF INTERIM'REGERINGS'}

Die fisiese teenwoordigheid van die Filistyne in die kusvlakte en die Kanaänitiese stadstate in die vrugbare valleie en vlaktes, het die Israelitiese stamme redelik ingeperk gelaat in die yl bewoonde heuwellande. Ander etniese groepe, soos reeds genoem, het hulle ook reeds in die heuwellande tuisgemaak. In die noorde sou die vestiging van die Arameërs in Sirië en Mesopotamië ook die Israeliete inhibeer om enigsins in daardie rigting uit te brei.

Daar is reeds verwys na die uiteenlopende standpunte oor hoe die 'intog' van die Israelitiese stamme plaasgevind het. Wat wel met sekerheid uit argeologiese getuienis gesê kan word, is dat die proses van vestiging en uitbreiding na alle waarskynlikheid langer as tweehonderd jaar geduur het. Hierdie proses is nie net gekenmerk deur alliansie- en koalisievorming nie, maar ook deur oorloë en selfs burgeroorloë. Die opvallende eiesoortigheid in die materiële kultuur van die Israelitiese stamme word deur Aharoni (1978:19) vertolk as 'n sterk band wat tussen die groepe bestaan het.

Die vraag is nou watter politieke struktuur daar onder die Israelitiese stamme bestaan het. Die politieke prentjie van die Israelitiese stamme is moeilik definieerbaar, tog is dit nie onmoontlik om sekere afleidings te maak nie.

Lemche (1988:88) het veral op die belangrikheid van die Merneftastele, die Egiptiese inskripsie by Bet-sean en die Amarnabriewe gewys in die proses om die organisasie van die Israelitiese stamme beter te kan omskryf. Na 'n samevoeging van die gegewens uit die drie dokumente maak Lemche (1988:103) die belangrike afleiding dat die naam 'Israel' waarna die Merneftastele reeds in die dertiende eeu verwys, nie maar net nog ' $n$ stadstaat is nie, maar die naam van 'n spesifieke stamme-alliansie (waarskynlik Efraim, Manasse en Benjamin). Dié groep met die spesifieke naam 'Israel' het mekaar ondersteun en in tye van hoofsaaklik eksteme bedreiginge, gesamentlik opgetree.

Die belangrikheid van die 'apiru waarna die twee ander bronne verwys moet ook nie onderskat word nie, aldus Lemche (1988:103). Hierdie sosiale groepering wat die gesag van die Kanaänitiese stadstate uitgedaag het, hou 
moontlik verband met die Hebreërs van die Bybel. Of hulle verband hou met die 'Israel' waarna verwys word in die Merneftastele, is hoogs waarskynlik maar onseker. Die belangrikheid van die 'apiru-groep in hierdie verband is moontlik dat dit verder beklemtoon dat daar reeds vóór die tyd van die Rigters 'georganiseerde groepe' bestaan het waarby die Israelitiese stamme kon aansluit of self 'n soortgelyke organisasie of assosiasie kon vorm. Daar het heelwat sulke groepe onder die Israelitiese stamme bestaan wat stammeorganisasies of interimregerings genoem kan word.

So 'n groepering in dié gesegmenteerde gemeenskap kan moontlik in die eerste hoofstuk van die boek Rigters gevind word. Hier word die stamgebiede van slegs ses stamme beskryf (Efraim, Benjamin, Magir, Sebulon, Issaskar en Naftali). Aharoni \& Avi-Yonah (1979:68 vgl ook Noth 1983) vermoed selfs dat hierdie stamme 'n noordelike stammebond met Silo as hoofsentrum gevorm het. Dit is opvallend dat hierdie stamme in Rigters 1 soveel ooreenstem met die stamgroepering, onder leiding van Debora en Barak, wat in Rigters 5 genoem word (Efraim, Benjamin, Magir, Sebulon, Issaskar en Naftali).

'n Ander stamgroepering het moontlik later, nadat Magir ooswaarts verhuis het, ook in Transjordanië gefunksioneer (Reuben, Gad en Magir, Aharoni 1971:124). 'n Groot verskeidenheid ander families en clans, sommige in die westelike deel van Kanaän en ander in Gilead het hulself aan die groepering onderwerp (vgl Aharoni 1971:124). Die Rigters Jefta en Jaïr het waarskynlik in hierdie gebied opgetree.

Nog 'n stamme-assosiasie wat in hierdie verband genoem kan word, is dié in die stamgebiede van Juda en Simeon in die suide van die land. Die stamme het waarskynlik ook hier 'n analoë bondgenootskap gesluit, met Hebron as hulle hoofsentrum. Hierdie bondgenootskap kon ook ander stamme soos Kaleb. Kenas, Jeragmeël en die Keniete ingesluit het (vgl Aharoni \& Avi-Yonah 1979:53).

Fritz (1987:99) het gelyk wanneer hy sê dat die stamme of groeperinge se kapasiteit om gemeenskaplik op te tree, 'n mate van sosiale hiërargie en militêre organisasie veronderstel het. Die eensydige politieke ondersoek na die geskiedenis van die Israelitiese stamme in hierdie artikel gee geen antwoord op die vraag na die vorm wat hierdie organisasie aangeneem het nie - daar is nie sprake van ' $n$ sentrale gesag, 'n twaalfstammefederasie of amfiktionie onder die Israelitiese stamme te bespeur nie. Ander historiese dimensies soos byvoorbeeld die sosiale of godsdienstige organisasie sou hierby in berekening gebring moet word. In hierdie politieke oorgangstyd in die geskiedenis van Israel kan daar klaarblyklik slegs na stammeorganisasies of interim'regerings' verwys word. Die interimregerings het daarom waarskynlik 
uit groepe bestaan waarin alliansie- en koalisievorming aan die orde van die dag was, en 'n situasie van magsdeling en simbiose met die Kanaäniete 'n werklikheid. Dit was ' $n$ oorgangstyd in die sin dat die situasie in die land gewissel het tussen 'n stadstaat-georganiseerde boeregemeenskap (onder Egiptiese beheer) na 'n stammegemeenskap en weer terug na 'n staatgeorganiseerde gemeenskap (gedurende die monargie, Lemche 1988:101). Die 'oorgangstyd' impliseer egter nie 'n strukturele ontwikkeling in die rigting van 'n monargie nie.

Die hoogste gesag van die interimregerings het waarskynlik nie by 'n enkele persoon nie, maar by die oudstes en stamhoofde in die verskillende gebiede berus (vgl Lemche 1988:88). Die belangrikste aspek van die omstrede rol van die Rigter in hierdie tyd was seker sy of haar politieke of militêre leierskap om bedreiginge af te weer in dié hoogs vloeibare en onrustige tydperk in die geskiedenis van die Israelitiese stamme. Hierdie interimregerings wat hoofsaaklik in krisistye gefunksioneer het, het moontlik die klimaat geskep waarbinne die Israelitiese stamme ander samebindende faktore kon koester en kon die tradisies van die een groep mettertyd ook dié van al die ander stamme word.

\section{SLOT}

'n Afleiding wat uit die beskrywing van hierdie geskiedenis gemaak kan word is dat Israel nie noodwendig 'n eie afgebakende identiteit met hom saamgedra het nie. Hul identiteit was nie 'n gegewe entiteit nie, maar is gevorm deur die geskiedenis wat immers 'n dinamiese proses is wat sy eie loop neem terwyl 'n verskeidenheid invloede daarop inspeel. Identiteit kan ook nie ongeaffekteerd behou word nie. Die realiteit is dat identiteit saam met die geskiedenis groei en verander. Die geskiedenis is in wese 'n dinamiese krag wat juis nie bestaande identiteit fikseer nie, maar dit bekragtig en vernuwe. Israel moes inderdaad in die na-eksiliese tydperk fundamentele aanpassings beleef - en sou in die geskiedenis wat volg dit nog meer moes ervaar.

Hierdie soort studie het waarskynlik ook 'n belang vir ons hedendaagse politieke opset in die land. Watter identiteit word daar byvoorbeeld vandag aan die verskillende etniese groeperinge binne ons land se grense gekoppel?

\section{BIBLIOGRAFIE}

Aharoni, Y 1971. The settlement of Canaan. In Mazar, B (ed), The World History of the Jewish People, First Series: Ancient Times Volume III: Judges, 94-128. London: Allen.

Aharoni, Y 1978. The Israelite occupation of Canaan. An account of the archaeological 
evidence. In Aharoni, $M$ (ed), The archaeology of the land of Israel: from the prehistoric beginnings to the end of the First Temple Period, 14-23. Jerusalem: Shikmona.

Aharoni, Y \& Avi-Yonah, M 1979. Bybelse atlas. Durban: Butterworths.

Alt, A 1925. Essays on Old Testament history and religion. New York: Doubleday.

ANET 1950. Ancient Near Eastern Texts relating to the Old Testament, (ed) Pritchard, J B. Princeton: Princeton University.

Bright, J 1972. A history of Israel. Philadelphia: SCM.

De Geus, $\mathrm{C} \mathrm{H} \mathrm{J}$ 1976. The tribes of Israel. Amsterdam: Van Gorcum.

Deist, F E \& du Plessis, I J 1985, God en sy ryk. Pretoria: Van Schaik.

Dever, W G 1990. Recent archaeological discoveries and biblical research. Seattle: University of Washington.

De Vaux, R 1978. The early history of Israel to the period of the Judges. Vol 2. London: Darton Longman \& Todd.

Dothan, $\mathrm{T}$ 1984. In the days when the Judges ruled - research on the period of the settlement and the Judges. In Shanks. H \& Mazar, B (eds). Recent archaeology in the land of Israel, 35-42. Jerusalem: Israel Exploration Society.

Eybers, I H \& Annandale J 1975. Bybelse argeologie 204. Pretoria: Unisa.

Finkelstein, I 1988. The archaeology of the Israelite settlement. Jerusalem: Israel Exploration Society.

Fensham, F C \& Pienaar, D N 1982. Geskiedenis van Ou Israel. Pretoria: Academica.

Fritz, V 1981. The Israelite 'conquest' in light of recent excavations at Khirbet el-Mishnah. BASOR 241, 61-73.

Fritz, V 1987. Conquest of settlement? The early Iron Age in Palestine. $B A$ 50, 84-100.

Gottwald, N K 1979. The tribes of Yalweh. A sociology of the religion of liberated Israel. $1250-$ 1050 BCE. 2nd ed. London: SCM.

Gottwald, N K 1985. The Hebrew Bible - a socio-literary introduction. Philadelphia: Fortress.

Hamlin, E J 1990. At risk in the Promised Land. Edinburgh: Handsel.

Harrison, R K 1970. Old Testament times. Michigan: Eerdmans.

Jagersma, H 1982. A history of Israel in Old Testament times. London: SCM.

Kapelrud. A S 1969. The violent goddess. Oslo: Universitetforlaget.

Kitchen, K A 1988. Aram, Aramaeans. In Douglas, J D (ed), New Bible Dictionary, 2nd ed, 774-775. Leicester: Intervarsity Press.

Lemche, N P 1988. Ancient Israel. A new history of Israelite society. Sheffield: JSOT.

Lemche, N P 1989. A Scandinavian contribution to the understanding of the presence of God in the Old Testament. SJOT 1, 93-102.

Mazabow, G 1973. The indigenous population of Canaan. Its influence on the political, social, cultural and religous organization of early Israel. Unpublished MA Dissertation. Pretoria: Unisa.

Mazar, B (ed) 1971. The historical development. In Mazar, B (ed). The world history of the Jewish people. First series: Ancient times Vol III: Judges, 3-22. London: Allen.

Mazar, B 1981. Early Israelite settlement in the hill country. BASOR 241, 75-85.

Mendenhall, G E 1962. The Hebrew conquest of Palestine. BA 25, 66-87.

Miller, P C 1987. Aspects of the religion of Ugarit. In Miller, P D, Hanson, P D 6 McBride. S D (eds), Ancient Israelite religion, 53-66. Philadelphia: Westminster.

Miller, J M \&r Hayes, J H 1986. A history of ancient Israel and Judah. Philadelphia: Westminster. 
Mullen, E T 1993. Narrative history and ethnic boundaries. The Deuteronomistic historian and the creation of Israelite national identity. Atlanta: Scholars.

Noth, M 1966. The Old Testament world. London: Billing \& Sons.

Noth, M 1983. The history of Israel. London: SCM.

Redditt, L 1988. The Hittites. BI 15 (1), 40-48.

Richter, W 1964. Bonner Biblische Beitrage. Die Bearbeitungen des 'Retterbuches' in der Deuteronomischen Epoche. Bonn: Peter Hanstein.

Schwantes, S J 1965. A short history of the ancient Near East. Michigan: Grand Rapids.

Singer, I (ed) 1901. The Jewish Encyclopedia. New York: Ktav Publishing House.

Thompson, J A 1988. Ammon, Ammonites. In Douglas, J D (ed), New Bible Dictionary, 2nd ed, 30-31. Leicester Intervarsity Press.

Van Selms, A 1967. Genesis, deel I. Nijkerk: Callenbach.

Van Zyl, A H 1960. The Moabites. In Van Selms (ed), Pretoria Oriental series, Vol III, 1-240. Leiden: Brill.

Whitelam, K W 1989. Israel's traditions of origin: reclaiming the land. JSOT 44, 19-42.

Wright, G E 1966. Fresh evidence for the Philistine story. BA 29, 70-86.

Me $M$ le Roux

Departement Ou Testament

Universiteit van Suid-Afrika

Posbus 392

Pretoria

0001

Republiek van Suid-Afrika 